Available online at: www.jmi.mikoina.or.id

\title{
Potensi Simbiosis Cendawan Endofit pada Beberapa Tanaman Pangan dan Hortikultura
}

\section{Symbiosis Potential of Endophytic Fungi on Some Foods and Horticulture Crops}

\author{
Seviani DN ${ }^{1}$, Rahayu $\mathbf{G}^{1}$, Hidayat $\mathrm{I}^{2}$ \\ ${ }^{1}$ Departemen Biologi, Fakultas Matematika dan Ilmu Pengetahuan, Institut Pertanian Bogor, Bogor 16680 \\ ${ }^{2}$ Divisi Mikrobiologi, Pusat Penelitian Biologi, Lembaga Ilmu Pengetahuan Indonesia, Cibinong 16911
}

Seviani DN, Rahayu G, Hidayat I. 2017 - Potensi Simbiosis Cendawan Endofit pada Beberapa Tanaman Pangan dan Hortikultura. Jurnal Mikologi Indonesia 1(1), 1-10.

\begin{abstract}
Abstrak
Produktivitas tanaman pangan dan hortikultura seperti kedelai, sorgum manis, cabai, dan Chinese cabbage diduga dapat ditingkatkan melalui simbiosis dengan cendawan endofit. Cendawan endofit koleksi IPB Culture Collection strain IYT30, IYT50, IYT64, IYT65, dan IYT102 belum diketahui potensi endosimbiosisnya. Oleh sebab itu penelitian ini bertujuan untuk menguji potensi simbiosis cendawan endofit tersebut terhadap tanaman pangan dan hortikultura yaitu kedelai, sorgum manis, cabai, dan Chinese cabbage pada sistem interaksi kultur aksenik. Endosimbiosis diamati dengan adanya kolonisasi cendawan endofit pada jaringan akar, serta pertumbuhan tanaman inangnya (tinggi tajuk, jumlah daun, panjang akar, dan bobot kering biomassa). Hasil penelitian menunjukkan akar kedelai dan sorgum manis tidak dapat bersimbiosis dengan cendawan endofit pada kondisi uji. Oleh sebab itu pertumbuhan tanaman lebih dipengaruhi faktor-faktor selain simbiosis. Pada akar cabai dan Chinese cabbage, kolonisasi hanya mencapai ruang antar sel jaringan korteks, kecuali pada perlakuan IYT64 pada tanaman cabai dimana kolonisasi sampai ke dalam sel. Tanaman yang diinteraksikan dengan cendawan menunjukkan respon yang tidak konsisten pada semua parameter pertumbuhan.
\end{abstract}

Kata kunci - cendawan endofit - interaksi - kolonisasi - simbiosis

\begin{abstract}
Productivity of food and horticulture crops such as soybean, sweet sorghum, chili, and Chinese cabbage can be increased through symbiosis with endophytic fungi. Endosymbiosis potential of five IPB Culture Collections of endophytic fungal strainsi i.e. IYT30, IYT50, IYT64, IYT65, and IYT102 have not been explored yet. Thus, this research was aimed at testing endophytic symbiosis potential of those isolates with soybean, sweet sorghum, chili, and Chinese cabbage in an axenic culture system. Endosymbiosis was indicated by colonization root by the fungus and also by the growth of the host plant (height, number of leaves, root length, and dry weight biomass). The result symbiosis was not formed between endophytic fungi and soybean and sweet sorghum. Plant growth may apparently affected by other factors besides symbiosis. In contrast, chili and Chinese cabbage roots might be colonized by all fungal isolates. Mycelium of all fungi grew intercellularly in cortical layer,
\end{abstract}


except IYT 64 mycelium in chili root which grew intracellularly. Growth response of all treated plants was inconsistent in all parameters.

Key words - colonization - endophytic fungi - interaction - symbiosis

\section{Pendahuluan}

Kebutuhan hasil tanaman pangan dan hortikultura selalu meningkat setiap tahunnya seiring dengan peningkatan jumlah penduduk. Peningkatan produksi beberapa tanaman pangan dan hortikultura seperti kedelai, sorgum manis dan cabai menjadi prioritas pemerintah Indonesia (Dirjen Tanaman Pangan, 2012). Kedelai (Glycine max) merupakan tanaman legum yang mempunyai peranan penting sebagai bahan pangan, pakan, dan bahan baku industri. Kedelai kaya akan protein nabati, karbohidrat, dan lemak. Biji kedelai juga mengandung zat besi, fosfor, kalsium, vitamin B dengan komposisi asam amino yang lengkap (Rukmana \& Yuniarsih 2001). Peningkatan kebutuhan kedelai saat ini berasal dari kedelai impor karena produksi kedelai dalam negeri masih rendah (Zakiah, 2011).

Sorgum manis (Sorghum bicolor) merupakan salah satu tanaman serealia penting. Sorgum manis ditanam terutama untuk pakan ternak, dan sumber gula bahan baku industri etanol (Reddy et al, 2006). Nilai gizi dari sorgum manis dengan kandungan 83\% karbohidrat, 3.5\% lemak, dan $10 \%$ protein memadai untuk dijadikan bahan pangan dan pakan (Suarni, 2004). Selain biji sorgum manis yang memiliki kandungan nutrisi yang baik, batang sorgum manis juga memiliki kandungan gula yang cukup tinggi (Fernandez \& Curt, 2005).

Cabai (Capsicum annuum) merupakan komoditas hortikultura yang memiliki nilai ekonomi yang tinggi. Menurut Agustin et al. (2010) potensi produktivitas cabai bisa mencapai 20-40 ton/ha. Usaha untuk meningkatkan produktivitas cabai masih perlu dilakukan untuk memenuhi kebutuhan masayarakat. Salah satu kendala produksi cabai adalah adanya penyakit dan kualitas benih yang rendah (Duriat \& Muharam, 2003).

Selain tanaman pangan dan cabai, Chinese cabbage (Brassica rapa) merupakan salah satu jenis sayuran kelompok kubis-kubisan yang bernilai ekonomis tinggi. Chinese cabbage toleran terhadap suhu, sehingga tanaman ini memiliki daya adaptasi lebih luas (Hernowo, 2011). Chinese cabbage merupakan tanaman sayuran dengan umur panen pendek yakni 4050 hari setelah tanam yang memberikan peluang keuntungan yang layak untuk dikembangkan (Inonu et al, 2014). Selain itu, Chinese cabbage merupakan tanaman yang tidak berasosiasi dengan mikoriza dan dapat bersimbiosis dengan cendawan endofit (Ocampo et al, 1980).

Produktivitas kedelai, sorgum manis, cabai dan Chinese cabbage diduga dapat ditingkatkan melalui simbiosis dengan mikroba endofit. Salah satu mikroba endofit adalah cendawan endofit. Cendawan endofit hidup di dalam jaringan tanaman seperti daun, bunga, ranting, maupun akar tanaman dan menguntungkan tanaman tersebut tanpa menimbulkan gejala penyakit pada tanaman inangnya (Azevedo et al, 2000). Cendawan endofit memperoleh nutrisi dari tanaman inangnya, sebaliknya tanaman inang memperoleh proteksi terhadap patogen tanaman dari senyawa yang dihasilkan cendawan endofit (Carrol, 1988; Clay, 1988). Selain itu, cendawan endofit membantu tanaman lebih toleran terhadap lingkungan ekstrem dan tekanan terhadap faktor biotik dan abiotik (Schulz \& Boyle, 2005). Simbiosis yang menguntungkan tanaman ini menyebabkan kerusakan sel pada jaringan berkurang, meningkatkan kemampuan bertahan hidup, meningkatkan kemampuan fotosintesis serta meningkatkan pertumbuhan tanaman dan cendawan (Sinclair \& Cerkauskas, 1996).

Cendawan endofit dilaporkan dapat berasosiasi dengan inang yang luas yang terdiri dari 600 spesies tanaman dari 320 genus dan 110 famili (Diene et al, 2013). Potensi simbiosis cendawan endofit dengan tanaman perlu diketahui untuk membantu peningkatan pertumbuhan tanaman. Banyak cendawan endofit yang sudah diuji kemampuan endosimbiosisnya, 
namun lima isolat cendawan endofit koleksi IPB Culture Collection (IPBCC) (IYT30, IYT50, IYT64, IYT65, IYT102) belum diketahui potensi endosimbiosisnya. Oleh sebab itu potensi endosimbiosis cendawan ini dengan beberapa tanaman pangan dan hortikultura seperti kedelai, sorgum manis, cabai dan Chinese cabbage perlu diuji, sebelum dimanfaatkan secara luas.

\section{Metoda Penelitian}

\section{Persiapan Inokulum dan Bibit Tanaman}

Kultur stok lima cendawan endofit strain IPBCC IYT30, IYT50, IYT64, IYT65, dan IYT102 diremajakan pada media PDA cawan dan diinkubasi pada suhu $23{ }^{\circ} \mathrm{C}$ selama 4 minggu. Koloni ini siap dijadikan sumber inokulum bagi uji simbiosis. Benih kedelai, sorgum manis, cabai dan Chinese cabbage disterilisasi permukaannya menggunakan etanol $70 \%$ dan sodium hipoklorit $1 \%$, masing-masing selama satu menit. Sedangkan benih Chinese cabbage dan cabai disterilisasi permukaannya menggunakan etanol $70 \%$ dan sodium hipoklorit $1 \%$, masing-masing selama tiga puluh detik. Benih kemudian dibilas dengan air steril sebanyak tiga kali pencucian. Benih dikeringkan dalam petri yang berisi kertas saring steril, lalu benih ditanam secara aseptik pada media WA dan diinkubasi pada suhu $23{ }^{\circ} \mathrm{C}$ selama 3 hari. Bibit dengan bentuk dan ukuran yang seragam dipilih sebagai bahan uji simbiosis.

\section{Uji Potensi Endosimbiosis}

Uji simbiosis dilakukan dalam cawan petri yang berisi media OMA (Mahmoud \& Narisawa, 2013). Pertama-tama, media OMA dituangkan dalam cawan petri (berdiameter 25 $\mathrm{cm})$ steril sehingga terbentuk media miring. Cendawan diinokulasikan pada permukaan OMA dan diinkubasi selama 2-3 minggu. Sebanyak 3 bibit tanaman berumur 2-3 hari diletakkan bersentuhan dengan koloni cendawan (1 bibit/koloni) dalam setiap cawan petri. Bibit tanpa koloni cendawan dijadikan kontrol. Semua cawan diletakkan tegak dalam ruang tumbuh steril dengan penyinaran 12 jam terang dengan intensitas cahaya 1160 lux dan 12 jam gelap dan diinkubasi pada suhu $27{ }^{\circ} \mathrm{C}-30{ }^{\circ} \mathrm{C}$ selama 3 minggu. Uji dilakukan dengan delapan ulangan untuk setiap tanaman.

\section{Pengamatan}

Potensi endosimbiosis diamati dengan mengamati kemampuan hifa cendawan dalam mengolonisasi akar dan pertumbuhan tanaman uji. Pada akhir masa uji, sebagian tanaman dipisahkan akar dari bagian tajuknya untuk analisis endosimbiosis pada akar dan sebagian tanaman lain untuk diamati bobot biomassanya. Akar yang diwarnai dengan Tripan Blue 0.05\% (Kormanick \& McGraw, 1982), diamati kolonisasi cendawannya. Jumlah daun, tinggi tajuk, panjang akar dan bobot biomassa kering diamati pada minggu ke-3 setelah inokulasi. Bobot biomassa diamati setelah biomassa dikeringkan pada suhu $60{ }^{\circ} \mathrm{C}$ sampai dengan bobotnya stabil.

\section{Analisis Data}

Percobaan dilakukan dengan rancangan acak lengkap (RAL). Data dianalisis menggunakan program SPSS versi 22.0 dan diuji beda nyatanya dengan Duncan Multiple Range Test (DMRT) pada taraf 5\%.

\section{Hasil}

\section{Kolonisasi Cendawan Endofit pada Akar Tanaman Uji}

Pengamatan terhadap kolonisasi akar oleh cendawan merupakan cara untuk membuktikan adanya simbiosis. Kemampuan simbiosis cendawan endofit berbeda-beda bergantung 
pada tanaman ujinya. Kedelai dan sorgum manis yang diinokulasi cendawan tidak menunjukkan adanya kolonisasi dalam jaringan akar. Pada kedua tanaman ini hifa IYT30, IYT50, IYT65 tumbuh terbatas pada permukaan akar dan tidak ada hifa yang masuk ke dalam jaringan epidermis dan korteks (Gambar 1d-f). Bahkan akar yang diinokulasi dengan IYT64 dan IYT102 bebas dari hifa (Gambar 1b dan c).

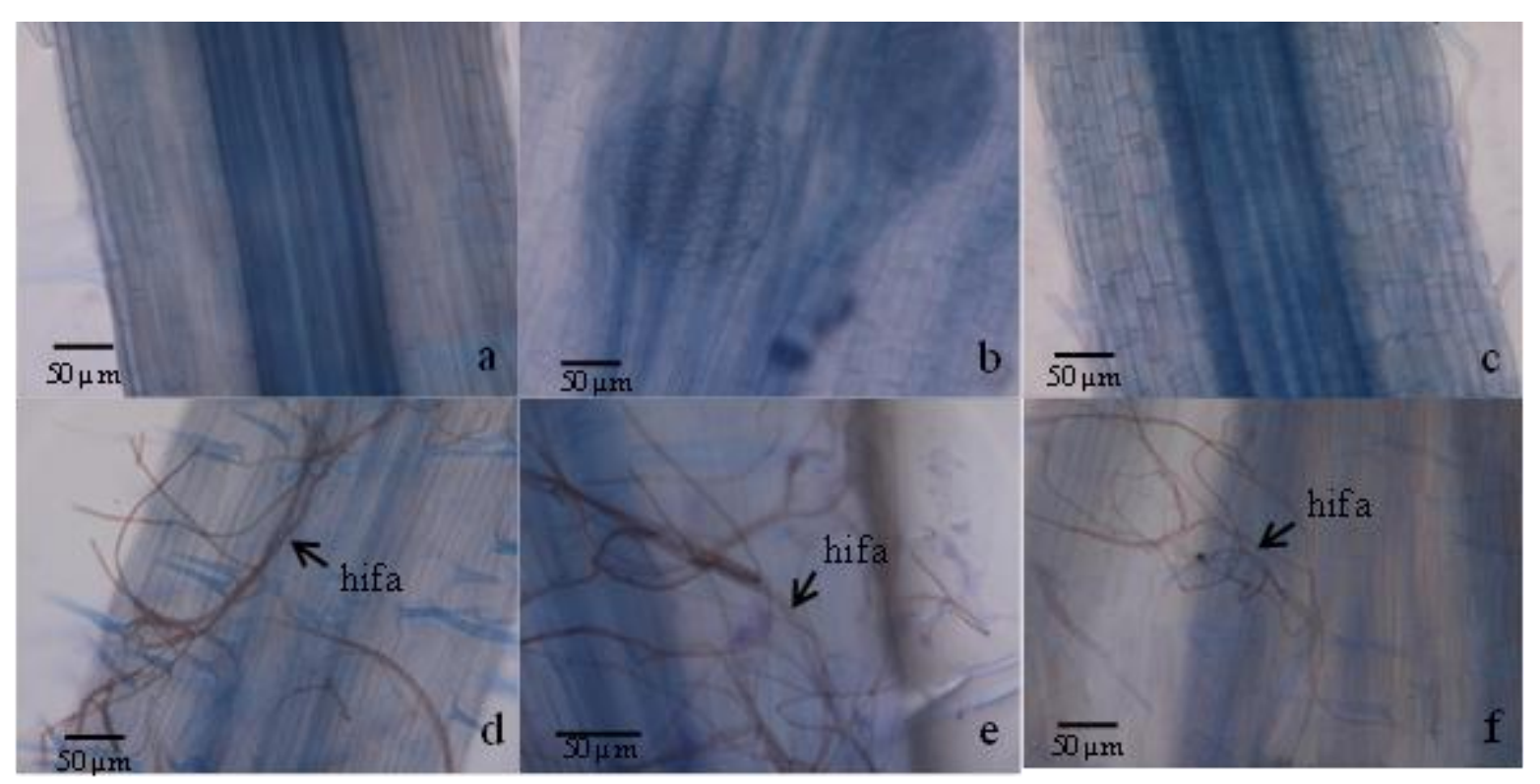

Gambar 1a-f. Akar sorgum manis. (a) tanaman kontrol dan akar sorgum manis yang diinokulasi dengan cendawan, (b) IYT 64, (c) IYT 102 yang tidak memperlihatkan adanya kolonisasi oleh cendawan, (d-f) akar sorgum manis dengan hifa cendawan IYT30, IYT50, dan IYT 65 di permukaannya.

Berbeda dari tanaman kedelai dan sorgum manis, pada cabai dan Chinese cabbage, cendawan mampu mengolonisasi akar. Pada tanaman cabai hifa cendawan uji tumbuh di ruang antar sel (Gambar 2b-e) kecuali hifa IYT64 masuk ke dalam sel pada jaringan korteks (Gambar 2f), sedangkan pada akar tanaman kontrol tidak terlihat adanya kolonisasi (Gambar 2a). Hifa semua cendawan tumbuh di ruang antar sel pada jaringan korteks akar tanaman Chinese cabbage (Gambar 3b-f), sedangkan pada akar tanaman kontrol tidak terlihat adanya kolonisasi (Gambar 3a).

\section{Respon Tumbuh Tanaman}

Simbiosis yang tidak terjadi pada akar tanaman kedelai dan sorgum manis menyebabkan tidak adanya konsistensi dalam peningkatan parameter pertumbuhan kedelai dan sorgum manis (Tabel 1). Sebaliknya, pada beberapa perlakuan parameter pertumbuhan tanaman justru kurang dari kontrol.

Uji endosimbiosis pada tanaman cabai dan Chinese cabbage menunjukkan cendawan endofit berpengaruh secara nyata hanya terhadap tinggi tajuk dan bobot kering biomassa. $\mathrm{Pa}$ da tanaman cabai perlakuan IYT64 meningkatkan secara nyata tinggi tajuk dan bobot kering tanaman (Tabel 1), sedangkan pada tanaman Chinese cabbage perlakuan IYT50 dan IYT64 meningkatkan secara nyata tinggi tajuk dan bobot kering biomassa (Tabel 1).

Kolonisasi cendawan yang tidak terlihat pada akar tanaman kedelai dan sorgum manis menunjukkan bahwa tidak terjadi simbiosis antara cendawan dengan akar kedua tanaman. Simbiosis tidak terjadi diduga dikarenakan adanya ketidaksesuaian antara cendawan dengan tanaman ujinya. Jumpponen (2001) menyatakan interaksi cendawan dan inang yang berbeda akan menghasilkan interaksi simbiosis yang berbeda. Kolonisasi yang terdapat pada tanaman 
cabai dan Chinese cabbage diduga terjadi karena tanaman tersebut cocok dengan cendawan uji. Jika suatu tanaman merupakan inang yang cocok bagi suatu cendawan, maka cendawan tersebut akan dapat lebih banyak mengolonisasi jaringan tanaman tersebut (Walker et al, 2003).

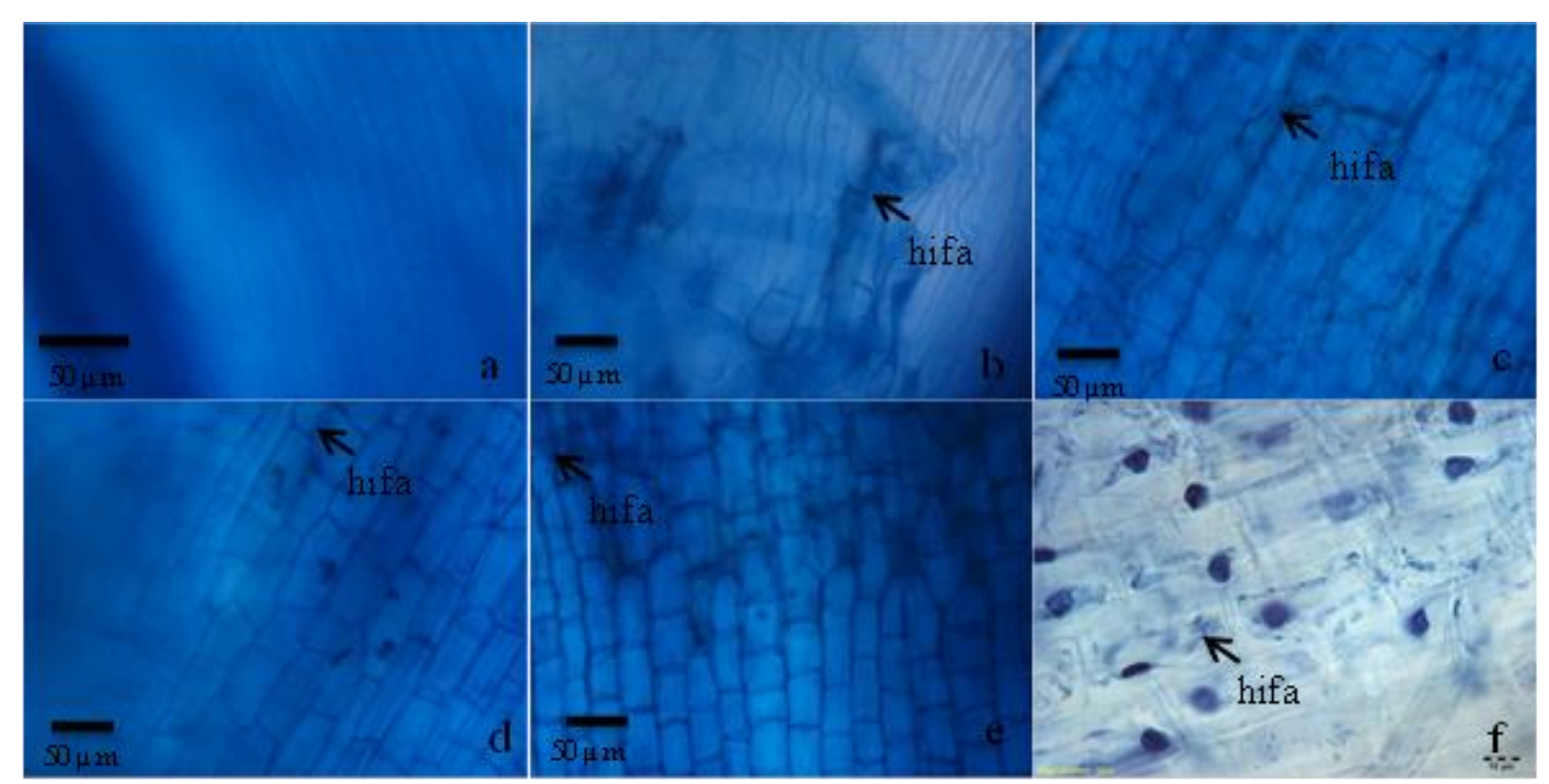

Gambar 2a-f. Akar cabai. (a) tanaman kontrol yang tidak memperlihatkan adanya kolonisasi, (b-e) akar cabai yang memperlihatkan adanya kolonisasi cendawan IYT30, IYT50, IYT 65, dan IYT 102 pada ruang antar sel jaringan korteks, (f) akar cabai yang memperlihatkan adanya kolonisasi IYT64 dalam sel jaringan korteks.

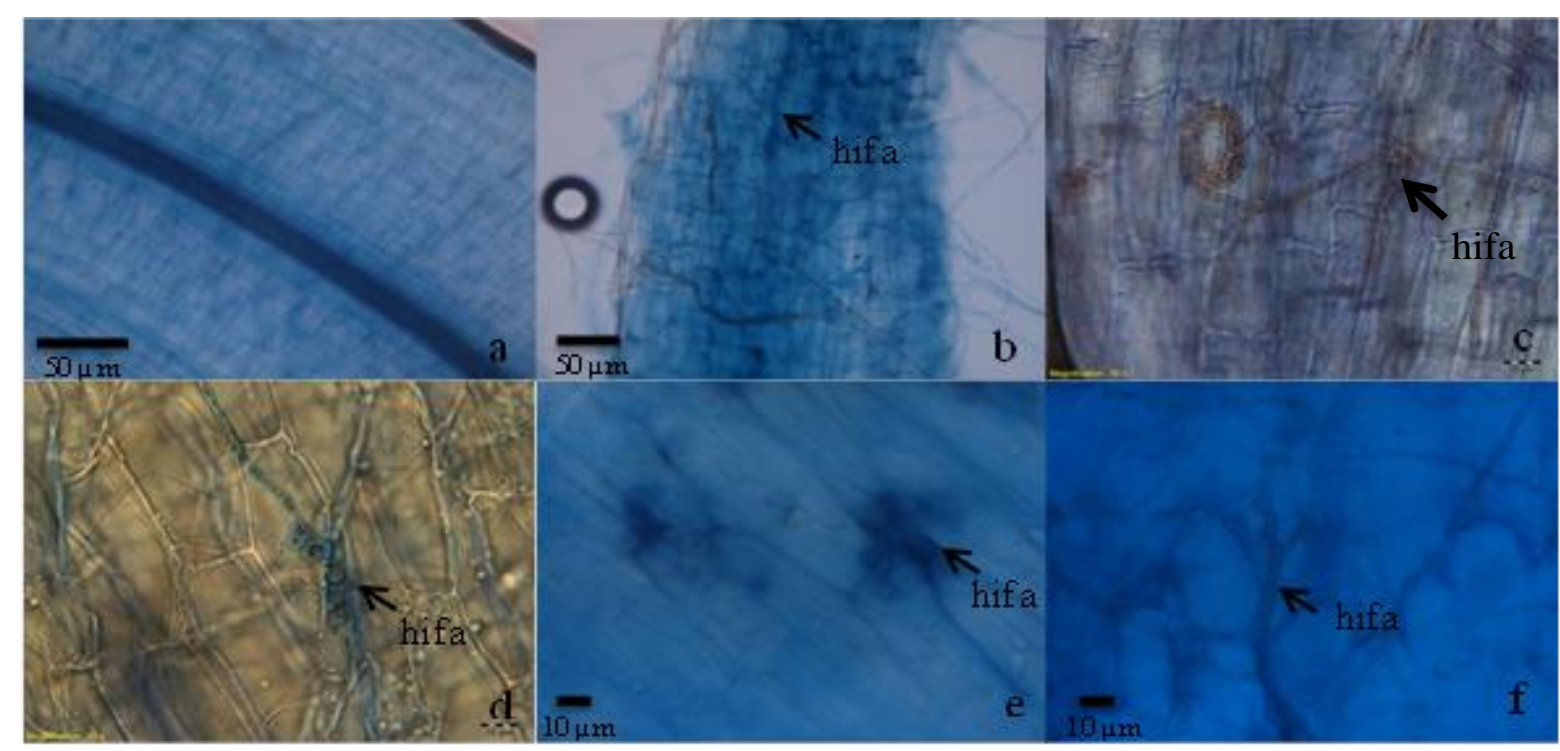

Gambar 3a-f. Akar Chinese cabbage. (a) tanaman kontrol yang tidak memperlihatkan adanya kolonisasi, (b-f) akar Chinese cabbage yang memperlihatkan adanya kolonisasi cendawan IYT30, IYT50, IYT64, IYT65 dan IYT102 pada ruang antar sel jaringan korteks.

\section{Kondisi Fisik Tanaman}

Secara umum kondisi fisik tanaman selama masa interaksi tidak bugar dan tidak tumbuh dengan baik. Akar pada sebagian besar tanaman, termasuk tanaman kontrol tidak dapat menembus agar. Akar-akar tumbuh sangat pendek dan kadang-kadang akar gagal menjangkar 
pada media tumbuh sehingga bibit rebah. Pada beberapa cawan terdapat media yang retak sehingga akar sulit tumbuh pada media. Akar-akar kedelai tidak tumbuh dengan baik dan ujungnya menghitam serta mudah hancur (Gambar 4a).

Tabel 1 Pengaruh cendawan endofit terhadap pertumbuhan tanaman pada media OMA.

\begin{tabular}{clcccc}
\hline Tanaman & Cendawan & $\begin{array}{c}\text { Tinggi tajuk } \\
(\mathbf{c m})\end{array}$ & $\begin{array}{c}\text { Panjang } \\
\text { akar }(\mathbf{c m})\end{array}$ & $\begin{array}{c}\text { Jumlah } \\
\text { daun }\end{array}$ & $\begin{array}{c}\text { Bobot kering (g) } \\
\text { Biomassa }\end{array}$ \\
\hline \multirow{6}{*}{ Kedelai } & Kontrol & $6.39^{\mathrm{a}}$ & $3.26^{\mathrm{b}}$ & $1.50^{\mathrm{bc}}$ & $0.1896^{\mathrm{a}}$ \\
& IYT30 & $5.63^{\mathrm{a}}$ & $3.12^{\mathrm{b}}$ & $1.12^{\mathrm{cd}}$ & $0.1920^{\mathrm{a}}$ \\
& IYT50 & $6.34^{\mathrm{a}}$ & $3.29^{\mathrm{b}}$ & $1.50^{\mathrm{bc}}$ & $0.1672^{\mathrm{b}}$ \\
& IYT64 & $6.48^{\mathrm{a}}$ & $3.11^{\mathrm{b}}$ & $2.00^{\mathrm{a}}$ & $0.1972^{\mathrm{a}}$ \\
& IYT65 & $5.37^{\mathrm{a}}$ & $3.87^{\mathrm{a}}$ & $1.00^{\mathrm{d}}$ & $0.1702^{\mathrm{b}}$ \\
& IYT102 & $6.47^{\mathrm{a}}$ & $3.49^{\mathrm{ab}}$ & $1.87^{\mathrm{ab}}$ & $0.1276^{\mathrm{c}}$ \\
\hline \multirow{6}{*}{ Sorgum } & $5.35^{\mathrm{ab}}$ & $0.81^{\mathrm{a}}$ & $5.00^{\mathrm{bc}}$ & $0.0536^{\mathrm{abc}}$ \\
& Kontrol & $5.17^{\mathrm{b}}$ & $0.94^{\mathrm{a}}$ & $5.37^{\mathrm{ab}}$ & $0.0406^{\mathrm{cd}}$ \\
& IYT30 & $5.40^{\mathrm{ab}}$ & $0.86^{\mathrm{a}}$ & $5.12^{\mathrm{bc}}$ & $0.0660^{\mathrm{a}}$ \\
& IYT50 & $5.39^{\mathrm{ab}}$ & $0.92^{\mathrm{a}}$ & $5.00^{\mathrm{bc}}$ & $0.5000^{\mathrm{bc}}$ \\
& IYT64 & $5.47^{\mathrm{a}}$ & $0.85^{\mathrm{a}}$ & $4.75^{\mathrm{c}}$ & $0.0292^{\mathrm{d}}$ \\
& IYT65 & $5.26^{\mathrm{ab}}$ & $0.96^{\mathrm{a}}$ & $5.62^{\mathrm{a}}$ & $0.0640^{\mathrm{ab}}$ \\
\hline \multirow{6}{*}{ Cabai } & IYT102 & $1.24^{\mathrm{bc}}$ & $0.36^{\mathrm{ab}}$ & $1.71^{\mathrm{a}}$ & $0.0045^{\mathrm{b}}$ \\
& Kontrol & $1.05^{\mathrm{c}}$ & $0.35^{\mathrm{b}}$ & $1.57^{\mathrm{a}}$ & $0.0045^{\mathrm{b}}$ \\
& IYT30 & $1.41^{\mathrm{b}}$ & $0.40^{\mathrm{ab}}$ & $1.71^{\mathrm{a}}$ & $0.0050^{\mathrm{a}}$ \\
& IYT50 & $1.71^{\mathrm{a}}$ & $0.38^{\mathrm{ab}}$ & $2.00^{\mathrm{a}}$ & $0.0050^{\mathrm{a}}$ \\
& IYT64 & $1.29^{\mathrm{b}}$ & $0.37^{\mathrm{ab}}$ & $1.86^{\mathrm{a}}$ & $0.0045^{\mathrm{b}}$ \\
& IYT65 & $1.38^{\mathrm{b}}$ & $0.42^{\mathrm{a}}$ & $2.00^{\mathrm{a}}$ & $0.0045^{\mathrm{b}}$ \\
\hline \multirow{6}{*}{ cabbage } & IYT102 & $1.29^{\mathrm{b}}$ & $0.38^{\mathrm{a}}$ & $2.00^{\mathrm{a}}$ & $0.0013^{\mathrm{b}}$ \\
& Kontrol & $1.44^{\mathrm{ab}}$ & $0.41^{\mathrm{a}}$ & $2.00^{\mathrm{a}}$ & $0.0014^{\mathrm{b}}$ \\
& IYT30 & $1.73^{\mathrm{a}}$ & $0.42^{\mathrm{a}}$ & $2.00^{\mathrm{a}}$ & $0.0018^{\mathrm{a}}$ \\
& IYT50 & $1.85^{\mathrm{a}}$ & $0.44^{\mathrm{a}}$ & $2.00^{\mathrm{a}}$ & $0.0018^{\mathrm{a}}$ \\
& IYT64 & $1.68^{\mathrm{ab}}$ & $0.38^{\mathrm{a}}$ & $2.00^{\mathrm{a}}$ & $0.0015^{\mathrm{b}}$ \\
& IYT65 & $1.63^{\mathrm{ab}}$ & $0.43^{\mathrm{a}}$ & $2.00^{\mathrm{a}}$ & $0.0014^{\mathrm{b}}$ \\
\hline
\end{tabular}

Keterangan: Angka pada setiap kolom pada satu jenis tanaman yang diikuti oleh huruf yang sama tidak berbeda nyata pada taraf 5\% (DMRT).

\section{Pembahasan}

Kemampuan simbiosis suatu cendawan dengan tanaman dapat dilihat dari kolonisasi pada akar. Kolonisasi ditandai dengan terdapatnya benang-benang hifa berwarna biru, mikrosklerosia, klamidospora atau struktur cendawan lain pada akar setelah pewarnaan dengan biru tripan (Handayani, 2011). Secara umum akar tanaman kedelai dan sorgum manis pada kontrol yang ditumbuhkan pada media OMA tidak menunjukkan adanya kolonisasi cendawan dalam jaringan akar, begitu juga dengan akar yang diinokulasikan oleh cendawan. Pada perlakuan tertentu, hifa hanya berada pada permukaan akar kedua tanaman. Berbeda dari tanaman kedelai dan sorgum manis, pada tanaman cabai dan Chinese cabbage terlihat adanya kolonisasi pada ruang antar sel pada jaringan korteks, kecuali perlakuan IYT64 pada tanaman cabai kolonisasi terlihat sudah sampai kedalam sel pada jaringan korteks.

Takashima et al, (2014) menyatakan bahwa cendawan-cendawan yang diuji simbiosisnya ini adalah endosimbion pada akar Huperzia spp. asal Taman Nasional Gunung Gede Pangrango (TNGGP). TNGGP berada pada ketinggian 1000-3000 mdpl dengan suhu udara berkisar $10^{\circ} \mathrm{C}-18^{\circ} \mathrm{C}$ (BBTNGGP, 2009). Lokasi percobaan berada pada ketinggian $200 \mathrm{mdpl}$ dan suhu pada ruang tumbuh lebih panas dibandingkan dengan suhu asal cendawan tumbuh yaitu $26^{\circ} \mathrm{C}-28^{\circ} \mathrm{C}$. Hal tersebut seharusnya tidak mempengaruhi simbiosis dikarenakan 
cendawan endofit berfungsi untuk membantu tanaman lebih toleran terhadap lingkungan ekstrem. Menurut Rodriguez et al, (2009) simbiosis dapat membuat tanaman dan cendawan toleran terhadap suhu sampai $65^{\circ} \mathrm{C}$.
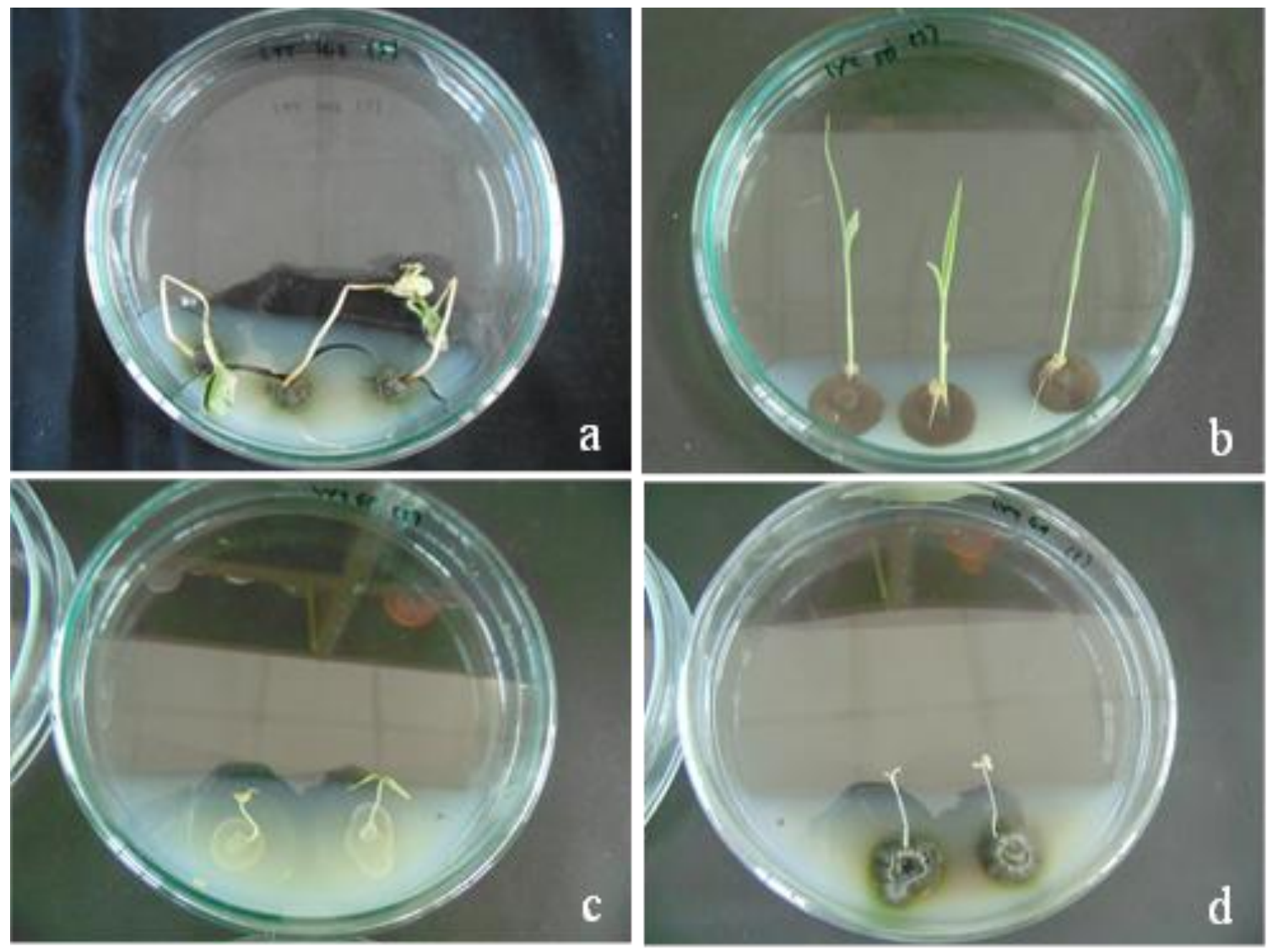

Gambar 4a-d. Kondisi fisik tanaman. (a) kedelai, (b) sorgum manis, (c) cabai, dan (d) Chinese cabbage pada media OMA yang tidak bugar dan tidak tumbuh dengan baik selama masa interaksi.

Cendawan-cendawan endosimbion yang ditemukan oleh Takashima et al, (2014) termasuk dalam tujuh genus yang teridentifikasi, empat diantaranya digunakan dalam penelitian ini yaitu Sclerotinia, Phialocephala, Leohumicola, dan spesies yang berkerabat dengan $\mathrm{He}$ lotiales. IYT30 diduga merupakan strain Sclerotinia trifoliorum yang diketahui menjadi cendawan patogen hanya pada tanaman alfalfa, semanggi merah, dan tanaman legum untuk pakan lainnya (Vleugels et al, 2010). IYT50 diduga merupakan strain Phialocephala yang dapat tumbuh pada tanah yang miskin hara. Phialocephala diduga menjadi endofit akar yang paling dominan di hutan (Mahmoud \& Narisawa, 2013). Cameron (1998) menemukan bahwa hifa Phialocephala dapat masuk sampai rambut akar dan berkas pembuluh, serta mikrosklerosia dapat tumbuh pada jaringan epidermis akar. Diene et al (2010) juga melaporkan bahwa Phialocephala sp. tidak meningkatkan secara nyata pertumbuhan sorgum manis. Isolat IYT64 dan IYT102 diduga merupakan strain Leohumicola yang diketahui memiliki toleransi terhadap suhu yang tinggi dan dapat bertahan hidup pada tanah panas sisa kebakaran lahan. Genus ini memproduksi koloni hifa pada akar dengan lambat (Hambleton et al, 2005). IYT65 diduga merupakan strain Helotiales yang dapat ditemukan pada tanaman hutan boreal serta dapat tumbuh pada lingkungan pasca pembakaran dan polusi logam berat (Vrålstad et al, 2002). Perbedaan karakteristik cendawan-cendawan tersebut menyebabkan respon tumbuh yang berbeda pada tiap tanaman. 
Uji simbiosis pada media OMA menunjukkan bahwa cendawan endofit berpengaruh nyata hanya terhadap beberapa parameter pertumbuhan terutama pada bobot kering biomassa. Beberapa penelitian sebelumnya melaporkan bahwa cendawan endofit dapat meningkatkan bobot kering biomassa pada sistem interaksi kultur aksenik (Diene et al, 2010; Mahmoud \& Narisawa, 2013). Simbiosis yang tidak terjadi dalam akar kedelai dan sorgum manis menyebabkan tidak ada cendawan yang secara konsisten meningkatkan semua paramater pertumbuhan. Perbedaan pertumbuhan tanaman bukan dikarenakan oleh simbiosis.

Hubungan yang terbentuk antara tanaman dan cendawan dapat berupa interaksi positif, netral maupun negatif (Jumpponen, 2001). IYT64 menunjukkan hubungan positif dengan tanaman cabai dan Chinese cabbage yang terlihat dari peningkatan secara nyata pada parameter tinggi tajuk dan bobot kering biomassa. Penelitian sebelumnya juga menyatakan Chinese cabbage yang diinokulasi cendawan endofit pada media OMA dapat meningkatkan pertumbuhan tanaman selama 21 hari masa interaksi (Narisawa et al, 2004). Kolonisasi cendawan endofit pada akar yang membentuk simbiosis dapat membantu penyerapan hara dan meningkatkan pertumbuhan tanaman (Maciá-Vicente et al, 2009). IYT30 memberikan hubungan negatif pada tanaman cabai dan Chinese cabbage yang terlihat dari pertumbuhannya yang kurang baik dibandingkan dengan tanaman kontrol. Berdasarkan hubungan negatif tersebut diduga $S$. trifoliorum dapat berpotensi sebagai cendawan patogen cabai dan Chinese cabbage.

Kondisi fisik tanaman yang tidak bugar dan tidak dapat tumbuh dengan baik selama masa interaksi menunjukkan kondisi lingkungan interaksi tidak mendukung pertumbuhan tanaman maupun terjadinya simbiosis. Kurangnya sirkulasi udara pada ruang tumbuh tanaman yang disebabkan karena penutupan cawan menggunakan seal selama masa interaksi diduga dapat menyebabkan tanaman tidak bugar dan mati. Hal ini dikarenakan tanaman membutuhkan udara untuk respirasi. Kurangnya oksigen dan akumulasi $\mathrm{CO}_{2}$ dalam ruang tumbuh tanaman juga diduga menjadi salah satu faktor tanaman tidak bugar dan mati. Hal tersebut sesuai dengan Hapsari \& Adie (2010) yang menyatakan bahwa kekurangan oksigen merupakan faktor pembatas pertumbuhan dan produktivitas tanaman, sehingga tanaman tidak bugar. Penampakan fisik tanaman kedelai yang tidak sebugar sorgum manis, cabai, dan Chinese cabbage disebabkan karena kebutuhan udara dan kemampuan hidup setiap tanaman berbeda. Tanaman kedelai termasuk ke dalam tanaman yang peka terhadap $\mathrm{CO}_{2}$, sehingga adanya akumulasi $\mathrm{CO}_{2}$ dapat menyebabkan tanaman mati (Boru et al, 2003).

Faktor yang mempengaruhi kondisi fisik tanaman yang kurang baik pada penelitian ini selain kurangnya sirkulasi udara adalah kondisi perakaran. Akar pada sebagian besar tanaman, termasuk tanaman kontrol tidak dapat menembus agar, padahal Mahmoud \& Narisawa (2013) menggunakan media yang sama untuk uji simbiosis Scolecobasidium humicola dengan bibit tanaman tomat. Media yang retak pada beberapa cawan diduga menyebabkan tanaman kedelai dan sorgum manis sulit mendapatkan hara karena akar tidak menembus agar dan menghambat proses pemanjangan akar sehingga akar menjadi pendek dan pertumbuhannya menjadi berkurang. Menurut Waty (2012) terhambatnya proses pemanjangan akar dapat menyebabkan hara yang terserap menjadi berkurang sehingga berpengaruh terhadap pertumbuhan tinggi serta bobot kering tajuk. Ukuran akar kedelai dan sorgum manis yang lebih besar dibandingkan ukuran akar cabai dan Chinese cabbage diduga menjadi faktor retaknya media. Oleh sebab itu diduga kondisi ruang tumbuh dan menanam tanaman dalam cawan petrilah yang tidak mendukung pertumbuhan tanaman.

\section{Ucapan Terima Kasih}

Penulis berterimakasih kepada Departemen Biologi, IPB dan Bidang Mikrobiologi, Pusat Penelitian Biologi, LIPI, atas bantuan fasilitas selama penelitian. 


\section{Pustaka}

Agustin W, Ilyas S, Budi SW, Anas I, Suwarno FC. 2010. Inokulasi fungi mikoriza arbuskula (FMA) dan pemupukan $\mathrm{P}$ untuk meningkatkan hasil dan mutu benih cabai (Capsicum annuum L.). J Agron Indones. 38:218-224.

Azevedo JL, Maccheroni JR, Pereira JO, Araujo WL. 2000. Endophytic microorganism: A review on insect control and recent advances on tropical plants. Elect Journal Biotech. 3:1-4.

[BBTNGGP] Balai Besar Taman Nasional Gunung Gede Pangrango. 2009. Revisi Zonasi Taman Nasional Gunung Gede Pangrango. Cianjur (ID): Departemen Kehutanan.

Boru G, Toai TTV, Alves J, Hua D, Knee M. 2003. Response of soybean to oxygen deficiency and elevated root-zone carbondioxide concentration. Annals Bot. 91:447453.

Cameron S. 1998. Colonization of Populus tremuloides seedlings by the fungus Phialocephala fortinii in the presence of the ectomycorrhizal fungus Thelephora terrestris [tesis]. Guelph (CA): Departemen Botani, Universitas Guelph.

Carrol GC. 1988. Fungal endophytes in stem and leaves: From latent pathogen to mutualistic symbiont. Ecol. 69:2-9.

Clay K. 1988. Fungal endophytes of grasses: A defensive mutualism between plants and fungi. Ecol. 69:10-16.

Diene O, Takahashi T, Yonekura A, Nitta Y, Narisawa K. 2010. A new fungal endophyte, Helminthosporium velutinum, promoting growth of a bioalcohol plant, sweet sorghum. Microbes Environ. 25:216-219.

Diene O, Wang W, Narisawa K. 2013. Pseudosigmoidea ibarakiensis sp. nov., a dark septate endophytic fungus from a cedar forest in Ibaraki, Japan. Microbes Environ. 28:381-387.

[Dirjen TP] Direktorat Jenderal Tanaman Pangan. 2012. Pedoman Pelaksanaan Program: Peningkatan Produksi, Produktivitas, dan Mutu Tanaman Pangan untuk Mencapai Swasembada dan Swasembada Berkelanjutan TA. 2012. Jakarta (ID): Dirjen TP.

Duriat, Muharam. 2003. Pengenalan Penyakit Penting pada Cabai dan Pengendaliannya Berdasarkan Epidemologi Terapan. Bandung (ID): Balitbang Pertanian.

Fernandez J, Curt MD. 2005. New energy crops for bioethanol production in the Mediterranean region. Int Sugar J. 107:622-627.

Hambleton S, Nickerson NL, Seifert KA. 2005. Leohumicola, a new genus of heat-resistant hyphomycetes. Stud in Myco. 53:29-52.

Handayani D. 2011. Potensi Aspergillus dan Penicillium asal serasah dipterocarp sebagai endosimbion akar pelarut fosfat [tesis]. Bogor (ID): Program Pascasarjana, Institut Pertanian Bogor.

Hapsari RT, Adie MM. 2010. Peluang perakitan dan pengembangan kedelai toleran genangan. J Litbang Pert. 29:50-57.

Hernowo B. 2011. Panduan Sukses Bertanam 20 Buah dan Sayuran. Jakarta (ID): Agromedia.

Inonu I, Khodijah NS, Supriadi A. 2014. Budidaya pakchoy (Brassica rapa L.) di lahan tailing pasir bekas penambangan timah dengan amelioran pupuk organik dan pupuk NPK. Prosiding Seminar Nasional Lahan Suboptimal 2014 [Internet]. [Waktu dan tempat pertemuan tidak diketahui]. Palembang (ID): MKTI. Hlm 68-75; [diunduh 2015 Juni 28].

Tersedia pada:http://www.purplsounsri.org/dokumen/68 ismedinonured.pdf\&sa=U\&ved=0CA0 QFjAAahUKEwiy44mHmZHHAhWCKogKHb7sASg\&usg=AFQjCNEitR276o2qm9H CZBFnXVWM2KIA5Q.pdf

Jumpponen A. 2001. Dark septate endophytes - are they mycorrhizal. Mycor. 11:207-211. 
Kormanick PP, McGraw AC. 1982. Quantification of Vesicular-Arbuscular Mycorrhiza in Plant Roots. St Paul (US): APS Pr.

Maciá-Vicente JG, Jansson HB, Lopez-Llorca LV. 2009. Assessing fungal root colonization for plant improvement. Plant Signal Behav. 4:445-447

Mahmoud RS, Narisawa K. 2013. A new fungal endophyte, Scolecobasidium humicola, promotes tomato growth under organic nitrogen conditions. PloS ONE. 8:e78746.

Narisawa K, Usuki F, Hashiba T. 2004. Control of verticillium yellows in Chinese cabbage by the dark-septate endophytic fungus LtVB3. Phytopathol. 94:412-418.

Ocampo JA, Martin J, Hayman DS. 1980. Influence of plant interactions on vesiculararbuscular mycorrhizal infections. Host and non-host plants grown together. New Phytol. 84:27-35.

Reddy BVS, Ramesh S, Reddy PS, Kumar AA, Sharma KK, Chetty SMK, Palaniswamy AR. 2006. Sweet Sorghum : Food, Feed, Fodder, and Fuel Crop. India (IN) : ICRISAT.

Rodriguez RJ, White Jr JF, Arnold AE, Redman RS. 2009. Fungal endophytes: Diversity and functional roles. New Phytol. 2:73-90.

Rukmana R, Yuniarsih Y. 2001. Kedelai Budidaya dan Pasca Panen. Yogyakarta (ID): Kanisius.

Schulz B, Boyle C. 2005. The endophytic continuum. Mycol Res. 109:661-686.

Sinclair JB, Cerkauskas RF. 1996. Latent infection vs endophytic colonization by fungi. Di dalam: Redlin SC, Carris LM, editor. Endophytic Fungi in Grasses and Woody Plants : Systematics, Ecology and Evolution. St Paul (US): APS Pr. hlm 23-29.

Suarni. 2004. Evaluasi sifat fisik dan kandungan kimia biji sorgum setelah penyosohan. $J$ Stigma. 12:88-91.

Takashima Y, Narisawa K, Hidayat I, Rahayu G. 2014. First report on fungal symbionts of Lycopodiaceae root from mount Gede Pangrango National Park Indonesia. J Dev Sus Agr. 9:81-88.

Vleugels T, Baert J, De Riek J, Heungens K, Malengier M, Cnops G, Van Bockstaele E. 2010. Diversity study on Sclerotinia trifoliorum Erikks., the causal agent of clover rot in red clover crops (Trifolium pratense L.). Commun Agric Appl Biol Sci. 75:649-653.

Vrålstad T, Schumacher T, Myhre E. 2002. Molecular diversity and phylogenetic affinities of symbiotic root-associated ascomycetes of the Helotiales in burnt and metal polluted habitats. New Phytol. 155:131-148.

Walker ST, Bais HP, Grotewold E, Vicanco JM. 2003. Root exudation and rhizosphere biology. Plant Physiol. 132:33-51.

Waty R. 2012. Potensi Aspergillus niger dan Penicillium spp. sebagai endosimbion pelarut fosfat pada akar serealia [skripsi]. Bogor (ID): Institut Pertanian Bogor.

Zakiah. 2011. Dampak impor terhadap produksi kedelai nasional. Agrisep. 12:1-10. 